\title{
Jackrabbit densities on fair and good condition Chihuahuan desert range
}

\author{
ALIPAYOU DANIEL, JERRY HOLECHEK, RAUL VALDEZ, ACKIM TEMBO, LEWIS \\ SAIWANA, MICHAEL FUSCO, AND MANUEL CARDENAS
}

\begin{abstract}
Authors are graduate research assistant (deceased), professor and graduate research assistant, Dept. of Animal and Range Sci., N.M. State Univ., Las Cruces, 88003; and professor, Dept. of Exp. Sta., New Mexico State Univ., Las Cruces 88003 .
\end{abstract}

\begin{abstract}
This study was conducted on Chihuahuan desert range near Las Cruces, in southcentral New Mexico, to determine the relationship of blacktailed jackrabbit (Lepus californicus) densifies to good (GC) and fair (FC) range condition. The Soil Conservation Service procedure was used to classify ecological range condition. Line transect procedures were used to estimate jackrabbit populations from July 1988 to December 1990 . Concurrently vegetation cover and mean plant height were determined with the line intercept procedure. Jackrabbit densities on the fair condition range were higher $(P<0.10)$ than those on the good condition range. This difference is attributed to the fair condition range containing more protective cover and preferred forage than good condition range. Jackrabbit abundance showed no season $(P<0.10)$ or year differences $(P<0.10)$. Jackrabbits preferred grass-shrub mosaic habitats more than shrubland and grassland habitats. The need for diverse food sources and protective cover were apparently major determinants of habitat selection by jackrabbits. The good condition range contained greater $(P<0.10)$ grass cover and less $(P<0.10)$ shrub cover than the fair condition range. Our results indicated that maintaining Chihuahuan desert ranges in good to excellent condition is the best means of achieving lower abundance of jackrabbit populations.
\end{abstract}

Key Words: rangeland, wildlife, grazing, rabbits, arid lands

The Chihuahuan desert rangelands of southcentral New Mexico historically were an open grassland or a grassland with scattered shrubs (Buffington and Herbel 1965). Presently, much of this area supports a mixture of shrubs and grasses. Mesquite (Prosopis spp.), catclaw (Acacia sp.), and creosotebush (Larrea tridentata Lar.) are common throughout the area (Holechek et al. 1989). The increase in these shrubs during the past 100 years (Humphrey 1958) has reduced forage production on many Chihuahuan desert rangelands. Livestock grazing probably will continue as an important rangeland use in the Chihuahuan desert (Holechek et al. 1989). Because of low forage productivity on Chihuahuan desert rangelands, livestock numbers must be carefully balanced with the forage supply in order to sustain grazing.

Jackrabbit (Lepus sp.) abundance can influence livestock grazing capacity (Vorhies and Taylor 1933, Currie and Goodwin 1966). High populations of jackrabbits in an area of scarce green forage can be destructive to the vegetation (Kalmback 1948). Better information on the relationship between range condition and jackrabbit populations in the Chihuahuan desert would permit more accurate estimates of grazing capacity. The main objective of this

The research was supported by the New Mexico Agr. Exp. Sta., Las Cruces and was part of project 1-5-274174.

Manuscript accepted 1 May 1993. study was to determine the influence of fair and good range condition on populations of black-tailed jackrabbits (Lepus californicus) in Chihuahuan desert rangelands in southcentral New Mexico.

\section{Description of Study Area}

The study was conducted on the College Ranch (CR) and adjacent Bureau of Land Management (BLM) rangeland in Dona Ana County, New Mexico, $37 \mathrm{~km}$ north of Las Cruces. The College Range and BLM study areas were 2,993 ha and 10,342 ha respectively, in the southern portion of the Jornada del Muerto Plain between the San Andres Mountains and the Rio Grande. Elevation of the study area varied from 1,330 to $1,348 \mathrm{~m}$ above sea level (Wood 1969, Valentine 1970).

The area is arid, with no permanent water except for the river and stock watering points supplied by wells and temporary earthen tanks. Annual precipitation during the study period varied from 190 to $296 \mathrm{~mm}$, with a 30-year (1961 to 1990) average of $248 \mathrm{~mm}$. About half of the annual precipitation occurs between July and September with the highest precipitation in August. Wood (1969) described the climate of the area as semidesert with temperatures varying from $-23^{\circ}$ to $42^{\circ} \mathrm{C}$ and extreme daily fluctuations of $30^{\circ}$ C. During the study period, average maximum annual temperatures varied from $23.6^{\circ} \mathrm{C}$ in 1988 to $25.1^{\circ} \mathrm{C}$ in 1990 , and average minimum varied from $1.6^{\circ}$ to $6.6^{\circ} \mathrm{C}$, respectively. June was the warmest month and January was the coldest.

Soils of the College Ranch and the BLM study areas are mainly light loamy sandy loams underlain by calcium carbonate hardpan (caliche) at depths varying from a few centimeters to $1 \mathrm{~m}$ or more (Valentine 1970, Fatehi 1986, Tembo 1990). They are classified as fine loamy, mixed, thermic, typic haplargids and are in the Simona-Cruces associations (SCS 1980). In areas where the ground cover is sparse, sandy dunes are formed around the invading mesquite plants (Wood 1969). Over most of the College Ranch range, the soil profile is relatively well preserved and stable.

Study area vegetation is characterized as Chihuahuan desert grassland, with shrubs scattered throughout the area. Large parts of the BLM land have been invaded by honey mesquite (Prosopis glandulosa Torr.). On the College Ranch the vegetation consists largely of black grama (Bouteloua eriopoda Torr.), mesa dropseed (Sporabolus flexuosus [Thurb.] Rybd.), and spike dropseed ( $S$. contractus A. Hitch.). Broom snakeweed (Gutierrezia sarothrae Greene) dominates a few small poor condition areas. A detailed description of vegetation and small mammals of the College Ranch is provided by Wood (1969) and a discussion of desert grassland vegetation by Pieper et al. (1983).

The College Ranch and BLM study areas were classified as in good and fair condition, respectively (Tembo 1990), with the 
Table 1. Density of black-tailed jackrabbits (rabbits/ha) on good and fair conditions Chihuahuan desert range.1

\begin{tabular}{|c|c|c|c|c|c|c|c|c|c|c|c|}
\hline $\begin{array}{l}\text { Range } \\
\text { condition }\end{array}$ & $\begin{array}{c}\text { Summer }^{2} \\
1988\end{array}$ & $\begin{array}{l}\text { Fall } \\
1988\end{array}$ & $\begin{array}{c}\text { Winter } \\
1989\end{array}$ & $\begin{array}{c}\text { Spring } \\
1989\end{array}$ & $\begin{array}{c}\text { Summer } \\
1989\end{array}$ & 1989 & $\begin{array}{c}\text { Fall } \\
1990\end{array}$ & $\begin{array}{c}\text { Winter } \\
1990\end{array}$ & $\begin{array}{c}\text { Spring } \\
1990\end{array}$ & $\underset{1990}{\text { Summer }}$ & $\begin{array}{c}\text { Fall } \\
\text { Mean }\end{array}$ \\
\hline$\cdots$ & & & & & - - rabbit & $1-=-2$ & 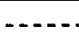 & 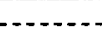 & $-\infty$ & מ - - - & - - - - - \\
\hline Good & $0.49^{\mathrm{a}}$ & $0.48^{\mathrm{a}}$ & $0.78^{n}$ & $1.00^{\mathrm{a}}$ & $0.55^{\mathrm{a}}$ & $0.50^{\mathrm{a}}$ & $0.87^{\mathrm{a}}$ & $0.33^{\mathrm{a}}$ & $0.23^{\mathrm{a}}$ & $0.40^{\mathrm{a}}$ & $0.56^{\mathrm{a}}$ \\
\hline Fair & $0.97^{\mathrm{a}}$ & $0.56^{\mathrm{a}}$ & $1.02^{\prime \prime}$ & $1.09^{\prime \prime}$ & $0.72^{b}$ & $0.84^{a}$ & $0.48^{b}$ & $0.87^{b}$ & $0.79^{b}$ & $0.46^{\mathrm{a}}$ & $0.78^{b}$ \\
\hline
\end{tabular}

'Counting months for seasons were June-August for summer, September-November for fall, December-February for winter, March-May for spring.

${ }^{2}$ Columns with different superscript letters $(a, b)$ denote significant differences in density cstimates $(P<0.10)$.

USDA Soil Conservation Service procedure developed by Dyksterhuis (1949). Remaining climax vegetation was approximately $65-70 \%$ on the College Ranch range and $35-40 \%$ on the BLM range (Tembo 1990). On a long-term basis (the last 25 years), the College Ranch range has been stocked for an average utilization level of about $30 \%$ on the key forage species compared with about $50 \%$ on the BLM range. During the last 10 years a stocking rate reduction of nearly $50 \%$ has been made on the BLM range. In the 1982 to 1990 period forage utilization on the BLM range was between 20 and $40 \%$ of current year growth. During the 1986-1990 period the actual stocking rate on the College Ranch and BLM ranges have averaged 48 ha and 67 ha per animal unit, respectively.

Several detailed vegetation inventories have been made on both the College ranch and BLM study areas since 1981 (McNeely 1983, Beck et al. 1987, Tembo 1990). Forage production and range condition scores increased between 1982 and 1990 on both ranges (Tembo 1990). This change was attributed to both above average rainfall and conservative stocking.

Grazing management on the BI.M range has involved a continuous grazing scheme. On the College Ranch range $45 \%$ of the area has been continuously grazed and $55 \%$ has been grazed under a best pasture grazing system since 1967

In the period from 1955 to 1964 various types of herbicidal brush control were applied to most of the College Ranch and BLM study areas. These treatments were evaluated on the College Ranch range by McNeely (1983) and Holechek and Fusco (1992). The most recent evaluations show more honey mesquite and broom snakeweed, but similar perennial grass standing crop on nonbrush control compared with the College Ranch study area (Holechek and Fusco 1992).

\section{Methods and Materials}

In each of the 2 study areas, 8 permanent line transects each 6.4 $\mathrm{km}$ long were established. Within each range condition class the transects were $500 \mathrm{~m}$ apart to avoid counting the same jackrabbits on more than 1 transect, and therefore insure statistical independence of the transects. Where the College Ranch and BLM range adjoined, transects were $500 \mathrm{~m}$ from the division fence to reduce boundary effects. All transects were marked with brightly colored plastic flagging at intervals of approximately $200 \mathrm{~m}$ or less depending on visibility. Survey design followed Anderson et al. (1979).

Counting of jackrabbits was initiated in July 1988 and continued through December 1990. From July 1988 to December 1989 counting was done monthly. In 1990 counting was done every other month. Counting was initiated at approximately 30 minutes after local sunrise and continued for 2 hours. Each study area was enumerated on the same day, and at the same time to minimize confounding from local migrations. Because each transect was 6.4 $\mathrm{km}$ long, each observer was limited to survey 1 transect/day. Transects were surveyed on foot and data recorded on the basis of perpendicular lateral distance measurement (Anderson et al. 1979, Burnham et al. 1980, Krebs 1989). For each individual or group of jackrabbits sighted, the perpendicular distance (in meters) to the path of the observer was estimated visually and verified periodi- cally by measurement.

A description of the plant community was recorded for each sighting. There were 3 major types of plant communities noted: (1) grassland (high seral) community which consisted mainly of black grama and dropseeds, and occasionally threeawns and tobosa grass, (2) shrub/grass (mid seral) mosaic which consisted of mesquite-dropseed-broom snakeweed, mesquite-threeawn-soaptree yucca, soaptree yucca-blackgrama-broom snakeweed, and broom snakeweed-dropseed, and (3) shrubland (low seral) community which consisted of mesquite-broom snakeweed-four wing saltbush, mesquite-acacia-broom snakeweed, and creosotebush-broom snakeweed.

\section{Vegetation Inventories}

Vegetation inventories were made along the same transects used for jackrabbit population estimates. Seven sampling periods to estimate cover and mean plant height were utilized between August 1988 and December 1990. Vegetation percent cover and height were sampled with the line intercept procedure of Canfield (1941) as modified by Holechek and Stephenson (1983). A 1-m stick, incremented in centimeters, was used instead of extended line. Along each transect at approximately $100 \mathrm{~m}$, the meter stick was horizontally lowered, with its mid-point on the transect line. The intercept and height of each plant species under the meter stick were measured. Cover of grasses, forbs, and shrubs were measured according to Bonham (1989), where grasses and forbs were measured at ground surface while shrubs and half-shrubs were measured on the crown spread intercept. Each transect consisted of 64-m sampling points. Becausc the meter stick was divided into $100-\mathrm{cm}$ units, vegetational intercepts were indirectly expressed and recorded as percentages of the meter stick. In each transect the percent intercept of each plant species was summed and divided by the total number of sampling points (64) to obtain the percent cover per sampling unit (transect). Mean plant height for each species were calculated by summing the height measurements and dividing by the number of sampling points where the plant species occurred.

\section{Statistical Analysis}

Jackrabbit numbers were summarized by range condition, season, year, and month. Densities (D) of jackrabbits in each range condition within a month were estimated with the Fourier Series Estimator (Burnham et al. 1980, Krebs 1989).

$$
D=\frac{\mathrm{nf}(0)}{2 \mathrm{~L}}
$$

Where:

$\mathrm{D}=$ estimated density

$\mathrm{n} \quad=$ number of jackrabbits seen on the transects that month

$f(0)=$ a probability density function estimated from maximum perpendicular distance recorded that month.

$\mathrm{L} \quad=$ average length of transect (modified by Krebs (1989) 
A repeated measure (split-plot) design was used (Steel and Torrie 1980) where range condition at 2 levels (good condition and fair condition) were the main plots and seasons and years as sub-plots. Jackrabbit densities were analyzed with analysis of variance (ANOVA) of General Linear Model (GLM) (Statistical Analysis System [SAS] 1985) to detect differences between range conditions and among seasons and years. Whenever there was condition by season by year interaction, the Least Significant Difference (LSD) test was performed to determine effect of range condition on density within season and the year at the $10 \%$ significance level.

Jackrabbit sighting data also were summarized by plant community types. Distribution of jackrabbit sightings among the plant communities were tabulated using frequency table procedure (SAS 1985).

A split-plot design was used to analyze the vegetation inventory data. Transects within range condition classes were defined as experimental units. Range condition at 2 levels (good condition and fair condition) were main plots and periods as sub-plots. Percent cover, and mean heights were analyzed with ANOVA (SAS 1985) to detect differences between range condition classes and interaction between range condition and period. Whenever there was a significant season and range condition interaction, the effect of range condition within each period was examined using the LSD test at 10\% significant levels (Steel and Torrie 1980).

\section{Results and Discussion}

Mean density of black-tailed jackrabbits was higher $(P<0.10)$ on the fair condition range than on good condition range (Table 1). Densities ranged from 0.23 to 1.00 jackrabbits/ha on good condition range and from 0.46 to 1.09 jackrabbits/ha on the fair condition range. These densities were similar to those reported by Norris (1950) and Herbel et al. (1970) on Chihuahuan desert ranges in south-central New Mexico ( 0.42 to 1.05 jackrabbits/ha). We consider jackrabbit populations during the study to be at moderate levels below the highs of the mid-1980's but above the lows of the early 1980's.

A combination of factors including availability of cover and forage may explain the tendency for higher jackrabbit densities on fair condition than good condition range. The fair condition range was characterized by relatively high shrub canopy cover compared to the good condition range (Table 2). This is attributed to past heavy grazing (prior to 1982) on the fair condition range compared to moderate grazing of the good condition range (Tembo 1990). Most of the shrub cover was comprised of snakeweed, honey mesquite, and soaptree yucca. These shrubs probably provide protective cover against predators and extreme climatic conditions. Predators such as coyotes may influence jackrabbit populations. Lechleitner (1958a) reported that in California jackrabbit resting places were often at the bases of large plants and seemed to be oriented to give maximum protection from the sun or high winds. Both Fautin (1946) and Lechleitner (1958b) noted that black-tailed jackrabbits selected stands of dense brush for resting but moved to more open communities for feeding.

Another factor that may explain the occurrence of higher densities of jackrabbits on the fair condition compared with good condition range may be forage availability. Food habits of jackrabbits in this study are reported by Daniel et al. (1993). This study showed jackrabbits fed on several plants but made greatest use of shrubs. Therefore jackrabbit abundance may have been greatest in shrubby habitats because food was more available. Fagerstone et al. (1980) attributed higher jackrabbit densities to proximity of preferred foods. However, in their study, jackrabbits showed an aversion to habitats with dense stands of shrubs. This is consistent with Taylor and Lay (1944), who found that eastern Texas jackrabbits were uncommon or absent in areas characterized by dense shrubs. In contrast, thin stands of shrubs favored jackrabbits.

In each season, more than $50 \%$ of the sightings occurred in the grass-shrub community and the remainder were divided between shrubland and grassland communities (Fig. 1). Shrubland, grassland and grass-shrub mosaics comprised $35 \%, 44 \%$, and $21 \%$ of the study area, respectively (Saiwana 1990). Grass-shrub habitats represent an ecotone or "edge" (Robinson and Bolen 1984) between the shrubland and grassland communities. "Edge" as used in this discussion refers to interspersion between the shrublands and grasslands. According to Leopold (1993) more resources are available to an animal in a smaller area when "edge effect" between

Table 2. Percent vegetation cover on the good condition (GC) and fair condition (FC) Chihuahuan desert study ranges in south-central New Mexico.

\begin{tabular}{|c|c|c|c|c|c|c|c|c|c|c|c|c|c|c|c|c|}
\hline \multirow[b]{2}{*}{ Species ${ }^{1}$} & \multicolumn{2}{|c|}{ Summer } & \multicolumn{2}{|c|}{ Winter } & \multicolumn{2}{|c|}{ Spring } & \multicolumn{2}{|c|}{ E. summer } & \multicolumn{2}{|c|}{ Spring } & \multicolumn{2}{|c|}{ Summer } & \multicolumn{2}{|c|}{ Winter } & \multicolumn{2}{|c|}{ Mean } \\
\hline & $\mathrm{GC}^{2}$ & FC & GC & $\mathrm{FC}$ & GC & $\mathrm{FC}$ & GC & $\mathrm{FC}$ & $\mathrm{GC}$ & FC & GC & $\mathrm{FC}$ & GC & $\mathrm{FC}$ & GC & $\mathrm{FC}$ \\
\hline \multicolumn{17}{|l|}{ Grasses } \\
\hline Aristida spp. & $4.7^{\mathrm{a}}$ & $2.4^{\mathrm{b}}$ & $5.0^{\mathrm{a}}$ & $1.4^{\mathrm{b}}$ & $3.4^{\mathrm{a}}$ & $2.1^{\mathrm{a}}$ & $5.7^{\mathrm{a}}$ & $1.4^{\mathrm{b}}$ & $3.1^{\mathrm{n}}$ & $1.6^{\mathrm{b}}$ & $3.8^{\mathrm{a}}$ & $1.8^{\mathrm{b}}$ & $2.9^{\mathrm{a}}$ & $1.6^{\mathrm{a}}$ & $4.1^{\mathrm{a}}$ & $1.8^{\mathrm{b}}$ \\
\hline Bouteloua barbarta & $\mathrm{T}$ & 0.4 & 0.0 & 0.0 & 0.0 & 0.3 & 0. & 0.0 & $T$ & $T$ & $0.1^{\mathrm{a}}$ & $0.3^{\mathrm{a}}$ & $0.3^{\mathrm{a}}$ & $0.4^{\mathrm{a}}$ & $0.1^{\mathrm{B}}$ & $0.2^{\mathrm{a}}$ \\
\hline Bouteloua aristidoides & $\mathrm{T}$ & 0.2 & 0.0 & 0.0 & 0.0 & 0.1 & 0.0 & 0.0 & $0.1^{\mathrm{B}}$ & $0.2^{\mathrm{a}}$ & $0.6^{\mathrm{a}}$ & $1.1^{\mathrm{a}}$ & $0.8^{\mathrm{a}}$ & $0.8^{\mathrm{a}}$ & $0.2^{\mathrm{a}}$ & $0.3^{\mathrm{a}}$ \\
\hline & $2.1^{\mathrm{a}}$ & $0.5^{\mathrm{a}}$ & $\begin{array}{l}.0 \\
7.3^{\mathrm{a}}\end{array}$ & $0.8^{\mathrm{b}}$ & $\begin{array}{l}0.0 \\
5.2^{\mathrm{a}}\end{array}$ & & & $0.3^{\mathrm{b}}$ & $3.1^{\mathrm{a}}$ & $0.9^{\mathrm{b}}$ & $4.0^{\mathrm{a}}$ & $0.6^{\mathrm{b}}$ & $2.3^{\mathrm{a}}$ & & $3.9^{\mathrm{a}}$ & $0.7^{\mathrm{b}}$ \\
\hline lum & $1.4^{\mathrm{a}}$ & $0.9^{\mathrm{a}}$ & $2.0^{\mathrm{a}}$ & $2.1^{\mathrm{a}}$ & $1.2^{\mathrm{a}}$ & $\begin{array}{l}0.0 \\
1.9\end{array}$ & 1.9 & $1.4^{\mathrm{a}}$ & $0.4^{\mathrm{a}}$ & $1.2^{\mathrm{b}}$ & $0.8^{\mathrm{a}}$ & $0.7^{\mathrm{a}}$ & $0.7^{\mathrm{a}}$ & 0. & $1.1^{\mathrm{a}}$ & $1.3^{\mathrm{a}}$ \\
\hline Pan & 0.0 & 0.1 & 0.0 & 0.0 & $T$ & 0.0 & 0 . & 0.0 & 0.1 & 0.1 & 0.0 & 0.4 & 0.1 & 0. & $\mathrm{~T}$ & 0.1 \\
\hline & 0.2 & 0.0 & 0.0 & 0.0 & 0.1 & & 0. & & $1.3^{\mathrm{a}}$ & $0.6^{\mathrm{a}}$ & $1.8^{\mathrm{a}}$ & $0.8^{\mathrm{a}}$ & $1.3^{\mathrm{a}}$ & 0. & $0.7^{\mathrm{a}}$ & $0.4^{\mathrm{a}}$ \\
\hline & $13.1^{\mathrm{a}}$ & $9.3^{\mathrm{a}}$ & $8.0^{\mathrm{a}}$ & $5.9^{\mathrm{a}}$ & $5.9^{\mathrm{a}}$ & $1.3^{\mathrm{b}}$ & 7.3 & $5.7^{\mathrm{a}}$ & $5.5^{\mathrm{a}}$ & $4.1^{b}$ & $9.2^{\mathrm{a}}$ & $4.6^{\mathrm{b}}$ & $6.6^{\mathrm{a}}$ & & $7.9^{\mathrm{a}}$ & $4.9^{\mathrm{b}}$ \\
\hline Total grasses & $21.6^{\mathrm{a}}$ & $13.5^{\mathrm{a}}$ & $22.3^{\mathrm{a}}$ & $10.2^{\mathrm{b}}$ & $15.8^{\mathrm{a}}$ & $7.0^{\mathrm{b}}$ & $17.9^{\mathrm{a}}$ & $8.8^{\mathrm{b}}$ & $13.6^{\mathrm{a}}$ & $8.7^{\mathrm{b}}$ & $20.3^{\mathrm{a}}$ & $10.3^{\mathrm{b}}$ & $15.0^{\mathrm{B}}$ & $9.2^{\mathrm{b}}$ & $18.0^{\mathrm{a}}$ & $9.7^{\mathrm{b}}$ \\
\hline \multicolumn{17}{|l|}{ Forbs/Shrubs } \\
\hline & $3.0^{\mathrm{a}}$ & $0.1^{\mathrm{b}}$ & 0.0 & & 0.0 & 0.0 & $2.1^{\mathrm{A}}$ & $0.0^{\mathrm{b}}$ & $0.9^{\mathrm{a}}$ & $0.0^{\mathrm{b}}$ & $2.6^{\mathrm{a}}$ & $0.4^{\mathrm{b}}$ & $1.2^{\mathrm{a}}$ & $0.1^{\mathrm{b}}$ & $1.4^{\mathrm{a}}$ & $0.1^{\mathrm{b}}$ \\
\hline ia sarothrae & $12.5^{\mathrm{a}}$ & $15.9^{\mathrm{b}}$ & $8.8^{\mathrm{a}}$ & $15.5^{\mathrm{b}}$ & $8.5^{\mathrm{a}}$ & $14.5^{\mathrm{b}}$ & $7.7^{\mathrm{a}}$ & $14.0^{\mathrm{a}}$ & $9.7^{\mathrm{a}}$ & $11.6^{\mathrm{a}}$ & $12.3^{\mathrm{b}}$ & $16.3^{\mathrm{b}}$ & $11.1^{\mathrm{a}}$ & $14.0^{\mathrm{a}}$ & $10.1^{\mathrm{a}}$ & $14.5^{\mathrm{b}}$ \\
\hline s glandulosa & $2.4^{\mathrm{a}}$ & $23.8^{\mathrm{b}}$ & $2.4^{\mathrm{a}}$ & $11.4^{\mathrm{b}}$ & $3.2^{\mathrm{a}}$ & $9.7^{\mathrm{b}}$ & $5.9^{\mathrm{a}}$ & $17.1^{\mathrm{b}}$ & $4.1^{\mathrm{a}}$ & $11.1^{\mathrm{b}}$ & $2.8^{\mathrm{a}}$ & $21.5^{\mathrm{b}}$ & $4.5^{\mathrm{a}}$ & $11.2^{\mathrm{b}}$ & $3.6^{\mathrm{a}}$ & $15.1^{\mathrm{b}}$ \\
\hline lata & $0.6^{\mathrm{a}}$ & $0.5^{\mathrm{a}}$ & $0.8^{\mathrm{a}}$ & $1.7^{\mathrm{a}}$ & $0.1^{\mathrm{a}}$ & $1.2^{\mathrm{b}}$ & $0.2^{\mathrm{a}}$ & $3.4^{\mathrm{b}}$ & $1.6^{\mathrm{a}}$ & $1.9^{\mathrm{a}}$ & $0.5^{\mathrm{a}}$ & $2.0^{\mathrm{b}}$ & $1.2^{\mathrm{a}}$ & $2.7^{\mathrm{a}}$ & $0.7^{\mathrm{a}}$ & $1.9^{\mathrm{b}}$ \\
\hline Total Forbs/Shrubs & $18.5^{\mathrm{a}}$ & $40.3^{\mathrm{b}}$ & $12.0^{\mathrm{a}}$ & $28.6^{\mathrm{b}}$ & $11.8^{\mathrm{a}}$ & $25.4^{\mathrm{b}}$ & $15.9^{\mathrm{a}}$ & $34.5^{\mathrm{b}}$ & $16.3^{\mathrm{a}}$ & $24.6^{\mathrm{a}}$ & $18.2^{\mathrm{a}}$ & $40.2^{\mathrm{b}}$ & $18.0^{\mathrm{B}}$ & $28.0^{\mathrm{b}}$ & $15.8^{\mathrm{a}}$ & $31.6^{b}$ \\
\hline Total Cover & $40.1^{\mathrm{a}}$ & $53.8^{\mathrm{b}}$ & $34.3^{\mathrm{a}}$ & $38.8^{\mathrm{a}}$ & 27.6 & 32.4 & $33.8^{\mathrm{a}}$ & $43.3^{\mathrm{b}}$ & $29.9^{\mathrm{a}}$ & $33.3^{\mathrm{a}}$ & $38.5^{\mathrm{a}}$ & $50.5^{\mathrm{b}}$ & $33.0^{\mathrm{a}}$ & $37.2^{\mathrm{a}}$ & $33.8^{\mathrm{a}}$ & $41.3^{\mathrm{b}}$ \\
\hline
\end{tabular}

ISplit-plot analysis of variance revealed condition $\times$ period interaction $(P \leq 0.10)$ in some of the species. Effect of range condition was therefore examined within period using least significant difference (LSD) tests.

${ }^{2} \mathrm{GC}=$ good condition range, $\mathrm{FC}=$ fair condition range.

Row means within period with different superscripts differ $(P \varangle 0.10)$.

Row means without superscripts no analysis was done due to insufficient data.

$\mathrm{T}=$ trace amount less than $0.1 \%$. 


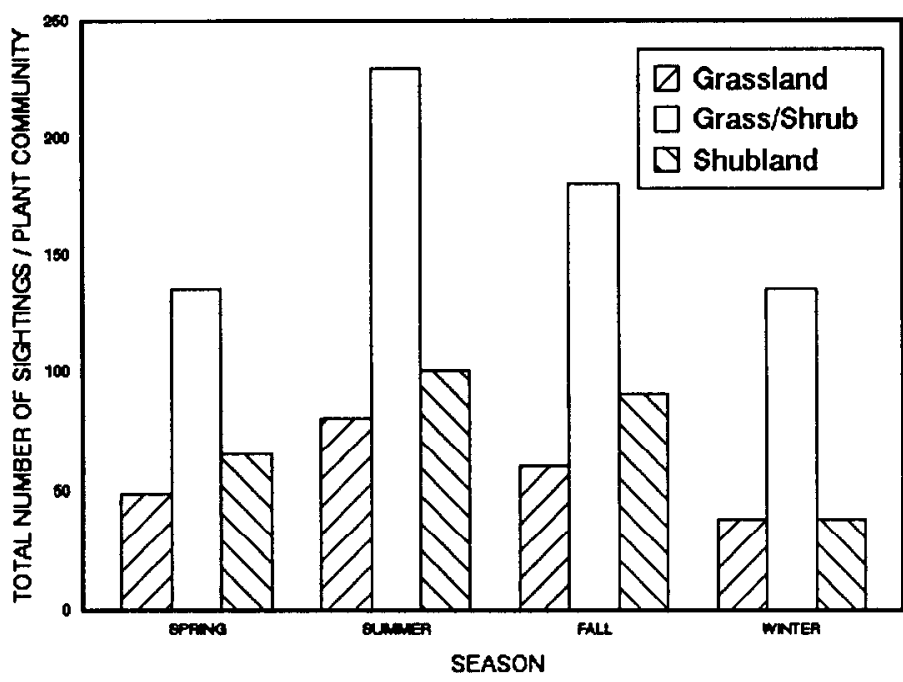

Fig. 1. Total sightings of jackrabbits on 2 range condition classes for 3 years of observation by plant community and season.

cover and food types is maximized. Thus, shrub-grass mosaic habitats probably provided jackrabbits with cover for protection and diverse food supplies. Shrublands were probably less preferred because they lacked diverse food resources and had reduced visibility, which would complicate escape from predators. Jackrabbits depend on speed and distance to escape predation (Leopold 1959, Fatehi 1986). The open grassland habitats also lacked diverse food resources (Daniel et al. 1993). Cover for protection against predators and extreme climatic conditions was diminished in the open grasslands.

Livestock grazing intensity during the period of study was similar between the good condition and fair condition ranges based on plant height. No differences in plant height $(P<0.05)$ occurred between black grama, threeawn, and mesa dropseed on good condition and fair condition ranges. Overall means were $34.3,26.8$, and $49.9 \mathrm{~cm}$, respectively. Use of current year's growth of key forage species averaged about $33 \%$ on both ranges (Tembo 1990). In the shortgrass prairie of Colorado, Flinders and Hansen (1975) found higher black-tailed jackrabbit populations on moderate and lightly grazed pastures than those that were heavily grazed. The moderate and light grazed pastures in their study were in good condition compared to the heavily grazed pastures, which were in poor-fair condition (Klipple and Costello 1960). Our results are inconsistent with their study in that we found higher black-tailed jackrabbit populations on the fair rather than good condition range. This may be explained by the fact we considered grazing pressure on both pastures during our study to be more moderate. Black-tailed jackrabbit populations may interact with grazing intensity, range condition, and range type. However, this needs to be better studied.

It is quite probable that black-tailed jackrabbits in our study influenced their habitat as well as being influenced by their habitat. Brown (1947) reported that leporids may distribute up to 14.2 $\mathrm{kg} / \mathrm{ha}$ of viable sand dropseed (Sporobolus cryptandrus [Torr.] Gray) seeds and thus may be a major factor influencing the subsequent stand of vegetation on occupied rangelands. Norris (1950) found exclusion of jackrabbits on poor condition honey mesquite range in the Chihuahuan desert could bring about major increases in desirable perennial forage grasses such as dropseeds. He believed jackrabbit control could speed perennial grass recovery on degraded areas. In contrast Daniel et al. (1993) found that poisonous plants and unpalatable shrubs dominated jackrabbit diets on the 2 ranges in our study. He believed jackrabbits may promote successional advance through their foraging pressure on unpalatable species such as honey mesquite, cactus (Opuntia sp.) and broom snakeweed.

\section{Experimental Limitations}

One limitation of study concerns the time of day we conducted our census counts. Our counts were conducted for 2 hours from about 30 minutes after sunrise. However, peak jackrabbit activity is nocturnal, and immediately after dusk appears to be one of the better times for censusing (Flinders and Hansen 1973, 1975). Since access to free water is restricted in the Chihuahuan desert, they probably minimize daytime activities to avoid dehydration. In our study on both ranges, approximately $44-55$ and $80-90 \%$ of the area, respectively, was within 1.6 and $32 . \mathrm{km}$ of livestock water. Black-tailed jackrabbits may move considerable distances between cover and water. Therefore, it is possible that use of the more open good condition area was greater than indicated by our census.

\section{Management Implications}

During 3 years of the study, black-tailed jackrabbit numbers were consistently higher on fair condition than good condition Chihuahuan desert range. Other studies in the western United States have shown higher jackrabbit populations under low compared to high range condition as judged by the quantitative climax approach developed by Dyksterhuis (1949). Increased levels of forbs and shrubs which jackrabbits require for food and cover may explain why jackrabbit populations initially increase as range condition declines (Daniel et al. 1993). Degraded shrubland areas in our study had more black-tailed jackrabbits than open grasslands. However jackrabbit numbers were highest in mid-seral plant communities with a mixture of grasses, forbs, and shrubs. Based on our findings the best approach to reducing abundance of blacktailed jackrabbits in the Chihuahuan desert is to maintain the range in good to excellent ecological condition. This can be accomplished by stocking these ranges so about one third of the current year's growth of the key forage species (mesa dropseed, black grama, threeawn) is removed by livestock (Holechek 1991, Holechek and Pieper 1992).

\section{Literature Cited}

Anderson, D.R., J.L. Laake, B.R. Crain, and K.P. Bunrham. 1979. Guidelines for line transect sampling of biological populations. J. Wildl. Manage. 43:70-78.

Beck, R.F., R.P. McNeely, and H.E. Kiesling. 1987. Seasonal grazing on black grama rangelands. Livestock Res. Brief, New Mexico Agr. Exp. Sta., Las Cruces.

Bonham, C.D. 1989. Measurements for terrestrial vegetation. John Wiley and Sons, N.Y.

Brown, H.L. 1947. Coaction of jackrabbit, cottontail and vegetation in a mixed prairie. Trans. Kansas Acad. Sci. 50:28-44.

Buffington, L.C., and C.H. Herbel. 1965. Vegetation changes on semidesert grassland range from 1958 to 1963. Ecol. Monogr. 35:139-164.

Burnham, K.P., D.R. Anderson, and J.L. Laake. 1980. Estimation of density from the line transect sampling of biological populations. Wild. Monogr. 72:1:202.

Canfield, R.H. 1941. Application of the line intercept method in sampling range vegetation. J. Forestry 39:388-394.

Currie, P.O., and D.L. Goodwin. 1966. Consumption of forage by blacktailed jackrabbits on semidesert rangeland. J. Wildl. Manage. 30:304-311.

Daniel, A., J.L. Holechek, R. Valdez, A. Tembo, L. Saiwana, M. Fusco, and M. Candenas. 1993. Range condition influences on Chihuahuan Desert cattle and jackrabbit diets. J. Range Manage. 46:296-301.

Dyksterhuis, E.J. 1949. Condition and management of rangeland based on quantitative ecology. J. Range Manage. 2:104-115.

Fagerstone, K.A., G.K. Lavoie, and R.E. Griffith, Jr. 1980. Black-tailed jackrabbit diet and density on rangeland and near agricultural crops. $J$. Range Manage. 33:229-232.

Fatehi, M. 1986. Comparative seasonal food habits of black-tailed jackrabbits and cattle on a semidesert rangeland. Ph.D. Diss. New Mexico State Univ., Las Cruces. 
Fautin, R.W. 1946. Biotic communities of the northern desert shrub biome in western Utah. Ecol. Monogr. 16:251-310.

Flinders, J.T., and R.M. Hansen. 1975. Spring population responses of cottontails and jackrabbits to cattle grazing shortgrass prairie. J. Range Manage. 28:290-293.

Flinders, J.T., and R.M. Hansen. 1973. Abundance and dispersion of leporids within a shortgrass ecosystem. J. Mammal. 54:287-291.

Fryxell, J.M., J. Greever, and A.R.E. Sinclair. 1988. Why are migratory ungulates so abundant? Amer. Natur. 131:781-798.

Fryxell, J.M., and A.R.E. Sinclair. 1988. Causes and consequences of migration by large herbivores. Trends in Ecol. and Evol. 3:237-241.

Herbel, C.H., P.L. Dittberner, and T.W. Bickle. 1970. A quantitative ecology of the Jornada Experimental Range. In: R.G. Wright, and G.M. Van Dyne (eds.). Simulation and analysis of dynamics of a semidesert grassland: An interdisciplinary workshop program toward evaluating the potential ecological impact of weather modifications. Range Sci. Dep. Sci. Ser. 6. Colorado State Univ., Fort Collins.

Holechek, J.L. 1991. Chihuahuan desert rangeland, livestock grazing and sustainability. Rangelands 13:115 120.

Holechek, J.L., and M. Fusco. 1992. Brush control versus grazing management influences on forage production and financial returns in the Chihuahuan desert. Livestock Res. Briefs and Cattle Growers' Short Course. N.M. Agr. Exp. Sta., Las Cruces.

Holechek, J.L., and R.D. Pieper. 1992. Estimation of stocking rate on New Mexico rangelands. J. Soil and Water Conserv. 77:116-119.

Holechek, J.L., R.D. Pieper, and C.H. Herbel. 1989. Range management principles and practices. Prentice Hall, Englewood Cliffs, N.J.

Holechek, J.L., and T. Stephenson. 1983. Comparison of big sagebrush range in northcentral New Mexico under moderately grazed and grazing excluded conditions. J. Range Manage. 36:455-456.

Humphrey, R.R. 1958. The desert grassland. Bot. Rev. 24:193-252.

Kalmback, E.R. 1948. Rodents, rabbits and grasslands: In: Grass. 1948. USDA Yearbook of Agriculture, p. 248-256.

Kreb, C.J. 1989. Ecological methodology. Harper and Row, Publ, N.Y.

Klipple, G.E., and D.F. Costello. 1960. Vegetation and cattle responses to different intensities of grazing on shortgrass ranges on the Great Plains. USDA Bull. 1216
Lechleitner, R.R. 1958a. Certain aspects of behavior of the black-tailed jackrabbit. Amer. Midl. Natur. 60:145-155.

Lechleitner, R.R. 1958b. Movements, density, and mortality in a blacktailed jackrabbit population. J. Wildl. Manage. 22:237-234.

Leopold, A. 1933. Game management. Charles Scribner's Sons, N.Y.

Leopold, A.S. 1959. Wildlife of Mexico: The game birds and mammals. Univ. California Press, Los Angeles.

McNeely, R.P. 1983. Influence of mesquite on vegetational changes under two grazing strategies in southern New Mexico. M.S. Thesis, New Mexico State Univ., Las Cruces.

Norris, J.J. 1950. Effect of rodents, rabbits and cattle on two vegetation types in semi-desert rangeland. New Mexico Agr. Exp. Sta. Bull. 353.

Pieper, R.D., J.C. Amway, C.H. Herbel, R.L. Packard, S.L. Pimm, R.J. Raitt, E.E. Staffeldt, and J.G. Watts. 1983. Structure and function of North American desert grassland ecosystems. New Mexico Agr. Exp. Sta. Res. Spec. Rep. 39.

Rohinson, W.L., and E.G. Bolen. 1984. Wildlife ecology and management. Macmillan Co., N.Y.

Saiwana, L.L. 1990. Range condition effects on scaled quail in southcentral New Mexico. Ph.D. Diss. New Mexico State Univ., Las Cruces.

SAS. 1985. User's guide: Statistics. Cary, N.C.

SCS. 1980. Soil survey of Dona Ana County Area. Las Cruces, N.M.

Steel, R.G.D., and J.H. Torrie. 1980. Principles and procedures of statistics. McGraw-Hill Book Co., N.Y.

Taylor, W.P., and D.W. Lay. 1944. Ecologic niches occupied by rabbits in eastern Texas. Ecol. 25:120-121.

Tembo, A. 1990. Influence of watering and range condition on vegetation of Chihuahuan desert. Ph.D. Diss. New Mexico State Univ., Las Cruces.

Valentine, K.A. 1970. Influence of grazing intensity on improvement of deteriorated black grama range. New Mexico Agr. Exp. Sta. Bull. 553.

Vorhies, C.T., and W.P. Taylor. 1933. The life histories and ecology of jackrabbits in relation to grazing in Wyoming. Arizona Agr. Exp. Sta. Tech. Bull. 49.

Wood, J.E. 1969. Rodent populations and their impact on desert rangelands. New Mexico Agr. Exp. Sta. Bull. 555. 